\title{
Granice rozwoju systemu politycznego UE po traktacie z Lizbony: pytanie o złożoność i odporność europejskiego systemu instytucjonalnego
}

\section{Wprowadzenie}

Obecny kształt systemu politycznego Unii Europejskiej (UE) jest efektem zmian zachodzących w obrębie struktury procesu integracyjnego od kilku dekad ${ }^{1}$. Tempo, kierunek i zaangażowanie poszczególnych aktorów w urzeczywistnianiu europejskiego projektu były zróżnicowane na kolejnych stadiach jego rozwoju. I o ile od początku założeniem był postęp w realizacji następujących po sobie etapów i zadań przypisywanych Wspólnotom Europejskim, w tym szczególnie Europejskiej Wspólnocie Gospodarczej (EWG), a potem Unii, to trudno o jednoznaczną ocenę w odniesieniu do zakładanych końcowych efektów współpracy. Rozwijane były wizje o bardzo zróżnicowanych założeniach teleologicznych, począwszy od projektów konfederacyjnych po konstrukcje superpaństwa europejskiego. Przejście na etap Unii Europejskiej pozwoliło ujrzeć w projekcie europejskim coś więcej niż zainteresowanie osiągnięciami ekonomicznymi. Okazało się, iż wspólnota, która narodziła się ponad 30 lat wcześniej, w latach pięćdziesiątych, nabiera charakteru nie tylko organizacji finansującej działania państw, ale zaczynała prezentować nową jakość europejskości w wymiarze politycznym, kulturowym i społecznym. Te bowiem sfery bardzo wyraźnie zaznaczyły się w nowej rzeczywistości integracyjnej, okazując jej nowe oblicze i wyznaczając nowe kierunki dalszego rozwoju (Wierzchowska, 2016, s. 281).

Integracja europejska podąża długą i wyboistą drogą, na której stale trzeba dokonywać wyborów, rozpoznawać długoterminowe korzyści i przezwyciężać przeszkody wynikające z konfliktów interesów (Cuyvers, 2017, s. 22). Konieczność dostosowywania się do zmieniających się celów zasadniczych, przy jednoczesnym reagowaniu na bieżące wydarzenia i wpływy zewnętrzne, ukształtowały w procesie integracji wyjątkowy (jakkolwiek nie zawsze w ujęciu korzystnym) sposób realizowania swojej ścieżki rozwoju. Towarzyszy jej naturalne dążenie do kształtowania stanu względnej równowagi całego systemu, dzięki czemu może on wypełniać swoje funkcje i zapewnić sobie przetrwanie (Wierzchowska, 2017, s. 11).

Po 1992 roku integracja europejska wstąpiła na ścieżkę bardzo intensywnych i znaczących przemian systemowych, jednak bez jasno sprecyzowanego finalite politique. W konsekwencji obecny system polityczny UE wydaje się nie mieć jasno wyznaczo-

${ }^{1}$ Publikacja sfinansowana w ramach programu Ministra Nauki i Szkolnictwa Wyższego „Dialog" w latach 2019-2021. 
nych granic swojego rozwoju. Jego dynamika jest określona z jednej strony bieżącymi dążeniami i wolą polityczną państw członkowskich kształtującymi wewnętrzne uwarunkowania rozwoju, z drugiej zjawiskami i procesami zewnętrznymi, które korygują pierwotne oczekiwania uczestników procesu integracji europejskiej. Istotne znaczenie ma fakt, iż cały proces odbywa się jednocześnie w warunkach dużej złożoności systemowej i szczególnych zdolności adaptacyjnych. Złożoność systemowa przejawia się w wielopoziomowości struktury czy szczególnych powiązaniach międzyinstytucjonalnych, które wpływają na kształtowanie się zróżnicowanego uczestnictwa w procesie integracji europejskiej. Obydwa komponenty uwzględniają zjawisko szczególnej relacji pomiędzy ponadnarodowością i międzyrządowością systemu integracyjnego (Wierzchowska, 2016, s. 181).

Reguły funkcjonowania tego systemu są określone w traktatach, jednak litera prawa nigdy nie oddawała rzeczywistego i praktycznego obrazu funkcjonowania systemu, w tym jego szczególnych zdolności adaptacyjnych.

Od 2009 roku UE znajduje się w reżimie prawnym wynikającym z traktatu lizbońskiego ${ }^{2}$, którego znaczenie i ocena dla procesu integracji nierozerwalnie łączy się z porażką ratyfikacyjną Traktatu ustanawiającego Konstytucję dla Europy w 2005 roku, jak splata się z wydarzeniami kryzysowymi rozlewającymi się po UE od 2008 roku. W kontekście badań nad systemem politycznym UE, jego złożonością i granicami rozwoju spojrzenie przez pryzmat traktatu z Lizbony pozwala dostrzec obecną rzeczywistość integracyjną jako współpracę naznaczoną doświadczeniami i kumulującą trudności przybierające postać kryzysu systemowego.

Celem badawczym pracy jest wskazanie na stan rozwoju systemu politycznego po 2009 roku, ze szczególnym uwzględnieniem przestrzeni instytucjonalnej i określenie najistotniejszych czynników wpływających na badany stan rzeczy. Hipotezą badawczą jest stwierdzenie, iż w efekcie implementacji traktatu z Lizbony pogłębiła się złożoność całego systemu integracyjnego, co w sposób szczególny uwidoczniło się w postlizbońskiej przestrzeni instytucjonalnej. Tym samym wzmocniła się konieczność i potrzeba elastycznych reakcji całego systemu na zachodzące procesy.

$\mathrm{Z}$ punktu widzenia metodologicznego, analiza będzie prowadzona $\mathrm{z}$ uwzględnieniem takich podejść jak teoria złożonych systemów adaptacyjnych, wielopoziomowy system zarządzania i koncepcja resilience.

Koncepcja resilience pozwala odnieść się do sposobu reagowania przez system (w szczególności system zdecentralizowany) na procesy zmian. Podkreśla ona jego zdolność do adaptacji i samonaprawy oraz obecność i oddziaływania mechanizmów instytucjonalnych prowadzących do ulepszania rezultatów społecznych (Rothert, 2017, s. 59). Wielowymiarowość i złożoność wymuszają w pewien sposób konieczność odejścia od tradycyjnego myślenia na temat mechanizmów przetrwania. Proste i oparte na sztywnych granicach reguły nie zdają tutaj egzaminu. Trzeba szukać innych, nierzadko doświadczalnych sposobów, które poprzez elastyczne i nowatorskie rozwiązania pozwolą uwzględnić wyjątkowe okoliczności rządzenia. Resilience w odniesieniu do struktur rządzenia to myślenie w kategoriach modeli sieciowych kreujących wciąż nowe połączenia pomiędzy złożoną rzeczywistością instytucjonalną, uwzględniającą ich egzystencję

\footnotetext{
${ }^{2}$ Traktat o Unii Europejskiej, Dz. Urz. UE C 326 z dnia 26 października 2012 r.
} 
formalną i nieformalną. Kategoria odporności kładzie nacisk na tworzenie warunków, które sprzyjają lepszej adaptacji i innowacyjności i dąży do wzmocnienia samoorganizacji i pojawienia się zachowań przystosowawczych, a nie na projektowaniu ściśle zarządzanych programów. Pozostawia więcej miejsca na ostrożny manewr w systemie, który jest z natury trudny do zmierzenia i przyjmuje bardziej iteracyjne (powtarzalne), ale nie linearne podejście do zmiany. Dla badań nad ponadnarodową przestrzenią integracyjną, resilience jest sposobem wyjaśniania właściwości adaptacyjnych systemu politycznego UE, które charakteryzuje przede wszystkim swoiste połączenie celowościowego i przewidywalnego działania z nieprzewidywalnymi zwrotami, korygującymi pierwotnie obrane założenia. Jest tym samym interpretacją mechanizmu utrzymywania (lub tracenia) równowagi systemowej (Wierzchowska, 2017, s. 13-20).

Wielopoziomowe rządzenie jest perspektywą badawczą, która koncentracje uwagę na fenomenie struktury, powiązań i mechanizmów współpracy oraz jej złożoności w procesie integracji. Wielość interpretacyjna tego podejścia sugeruje jego interdyscyplinarność i w efekcie pozwala na zróżnicowanie w jego implementacji. Jak zauważa Renata Mieńkowska: „Może być ono mianowicie postrzegane jako metoda badania współczesnej rzeczywistości politycznej w dobie globalizacji i europeizacji, obejmująca więcej aspektów niż tradycyjne metody odnoszące się do systemów politycznych państw narodowych. Wielopoziomowe rządzenie może być jednak także postrzegane jako normatywne podejście do międzyrządowego, ponadnarodowego sposobu podejmowania decyzji, włączającego partnerów społecznych i przedstawicieli społeczeństwa, które jest rozumiane o wiele szerzej niż naród (ujęcie horyzontalne), a także przedstawicieli poziomów regionalnego, lokalnego, ale też ponadnarodowego (ujęcie wertykalne)" (Mieńkowska, 2013, s. 57; za: Stein, Turkewitsch, 2010, s. 3-5).

Według niektórych badaczy jest to koncepcja, która nie do końca jeszcze ugruntowała się w obszarze badań politologicznych i studiów nad stosunkami międzynarodowymi. Jacob Borg sugeruje, iż wielopoziomowe sprawowanie rządów (MLG) jest stosunkowo nową koncepcją w literaturze dotyczącej stosunków międzynarodowych, która jeszcze nie znalazła swojego zrównoważonego miejsca w debacie na temat integracji Unii Europejskiej (Borg, 2012). Wskazuje on na autorów, którzy uważają MLG i same prace powstające wokół tego modelu zarządzania jako znajdujące się na ,etapie przedteoretycznym" (Jessop, 2010). Sugeruje także za Andrew Jordan, iż MLG jest istotnym opisem procesu decyzyjnego, zwłaszcza gdy odejdzie się od wewnętrznych niespójności analitycznych obecnych w sferze międzyrządowej (Jordan, 2001, s. 193-208). Podstawową przesłanką nowej koncepcji jest zwrócenie uwagi na fakt, iż integracja europejska odebrała władzę domenie państwowej i podzieliła ją między aktorów ponadnarodowych i subkrajowych (Marks, Hooghe, 1996, s. 342-378). Głównym elementem podejścia wielopoziomowego zarządzania jest postrzeganie architektury integracyjnej jako konstrukcji o wielu szczeblach: ponadnarodowym, międzyrządowym, narodowym, subnarodowym i złożonych relacjach pomiędzy nimi. Jednymi z pierwszych, którzy zaproponowali spojrzenie na system UE z tej perspektywy byli Gary Marks, Liesbet Hooghe i Kermit Black (Marks i in., 1996, s. 346).

W obrębie koncepcji MLG podkreśla się fenomen występowania wielu różnych poziomów uczestnictwa w systemie politycznym UE, co jest zarówno wzbogaceniem samego procesu, który staje się przez to odzwierciedleniem różnorodności europej- 
skiej przestrzeni partycypacyjnej, jak też implikuje zwiększony poziom rywalizacji lub co najmniej utrudniony dialog w zakresie różnych interesów. Dwie podstawowe kategorie interesów: narodowy i europejski są tutaj najistotniejszymi płaszczyznami dążeń. Interesy narodowe skoncentrowane wokół suwerennych kwestii, jak też specyfiki każdego państwa i jego potrzeb, są w niemal nieustannym napięciu w kontakcie z kolektywnymi dążeniami europejskimi. Nie mówimy tutaj o wyraźnej sprzeczności, ale z pewnością możemy mówić o poruszaniu się na kontinuum, którego dwa bieguny to polityka międzyrządowa i ponadnarodowa (Wierzchowska, 2017, s. 23).

Kategoria złożonego systemu adaptacyjnego stanowi ramę teoretyczną dla dwóch wcześniej wspomnianych podejść. Zarówno bowiem koncepcja resilience, jak i wielopoziomowe rządzenie realizują się w złożonych strukturach systemowych, stanowiąc dla nich rozwiązania możliwe do zastosowania w warunkach dużego zróżnicowania i dynamizmu przemian. Perspektywa złożonych systemów adaptacyjnych pozwala odkryć wiele specyficznych cech systemu integracyjnego, nie redukując go do jednowymiarowej płaszczyzny analitycznej, akcentującej proste i uporządkowane rozwiązania strukturalne (Wierzchowska, 2020, s. 778).

Wśród licznych definicji złożonego systemu adaptacyjnego możemy znaleźć takie, które eksponują aspekt wielości jego elementów wchodzących w interakcje w złożony, niejednorodny sposób (Albert i in., 2015, s. 2013), czy agregację jednostek współpracujących ze sobą i współtworzenie złożonych, adaptacyjnych wzorów zachowań (Boal i in., 2007, s. 413). W odniesieniu do procesu integracji wyraźnie wybijają się nielinearność zachodzących zmian, fragmentaryczność (układ jest zbudowany z różnych polityk, realizowanych na różnych zasadach prawnych, co sugeruje brak funkcjonalnej jednolitości systemowej), współzależność interakcyjna (cały proces decyzyjny opiera się na współpracy różnych aktorów państwowych i niepaństwowych), reguła feedbac$\mathrm{ku}$ (ustalenia na poziomie europejskim są weryfikowane w państwach podczas wyborów do PE), współpraca agentów (negocjacje z udziałem aktorów państwowych i pozapaństwowych), autonomia (państwa członkowskie są autonomiczne w odniesieniu do pewnych obszarów integracji, w których UE nie przejawia kompetencji) czy samoorganizacja, opierająca się zasadzie, że żaden z indywidualnych uczestników procesu integracyjnego nie ma wyłącznej kontroli nad procesem zmiany, która podlega samoorganizującej się sile czerpiącej zarówno z wewnątrz systemu, jak też z jego otoczenia. W praktyce oznacza to wypadkową dążeń największych państw członkowskich, konieczność brania pod uwagę koalicji regionalnych, oddziaływań uwarunkowań geopolitycznych czy nieprzewidzianych zdarzeń wymuszających modyfikacje we wcześniej założonym tempie i kierunkach procesu integracji (Wierzchowska, 2020, s. 783-784).

\section{Postlizbońska Unia Europejska - wybrane implikacje traktatu dla systemu politycznego UE}

Pojęcie postlizbońskiej Unii Europejskiej nie ogranicza się do samego fenomenu Unii jako prawnej organizacji określonej przepisami traktatowymi wynikającymi z dokumentu podpisanego w 2007 roku i obowiązującego od 1 grudnia 2009 roku. Jest to synonim obrazu integracji europejskiej, jaki wyłonił się wraz z podpisaniem traktatu 
lizbońskiego, z konsekwencjami, jakie przyniósł ze sobą kryzys euro i kolejne kryzysy pojawiające się w jego następstwie.

Podpisanie traktatu lizbońskiego miało stanowić istotny moment w procesie przełamywania impasu, w jakim integracja europejska znalazła się po nieudanej próbie wprowadzenia w życie traktatu konstytucyjnego. W ocenie wielu badaczy nie było to jednak do końca udane przedsięwzięcie. Dokument uwidocznił wiele z istniejących, ale nie do końca odkrytych problemów wewnętrznych procesu integracji, jak chociażby niespójne i ambiwalentne podejście do sposobu zastosowania demokracji w UE czy rozumienie spójności porządku prawnego. Kryzys wokół ratyfikacji traktatu pokazał, iż państwa członkowskie nie ,przemawiają jednym głosem” w sprawach integracji i co istotniejsze są w stanie poświęcić wartości demokracji dla przeforsowania pożądanych zmian ${ }^{3}$.

Pozostawiając bez głębszej analizy kwestię oceny szczegółowych modyfikacji instytucjonalnych traktatu lizbońskiego należy zwrócić uwagę na zmiany o charakterze systemowym i ich potencjale ukierunkowującym rozwój UE na kolejne dekady. Pytaniem jest czy traktat lizboński można nazwać przełomowym rozwiązaniem umacniającym tożsamość polityczną czy też jest to nie do końca zwieńczony sukcesem projekt wpisujący się w tradycję inkrementalnych procesów dostosowawczych. Ocena nie jest jednoznaczna i z pewnością zależy od obszaru obejmowanego analizą. Jak stwierdził Nigel Nugent, modyfikacje i zmiany ujęte w tym traktacie mają „mniejszy kaliber" niż te zawarte w postanowieniach Jednolitego Aktu Europejskiego czy traktatu z Maastricht (Nugent, 2012, s. 113). W tym kontekście można zauważyć rezygnację z umieszczenia w dokumencie odważnych przepisów o federalizacji procesu integracji i związanej z tym regulacji uznającej pierwszeństwo prawa europejskiego. Stanowiłoby to o wyraźnym przesunięciu torów procesu integracyjnego w stronę ponadnarodowości i rozszerzyłoby granice rozwoju systemu politycznego. Nie doszło jednak do zamieszczenia przepisu o prymacie prawa UE nad prawem krajowym w treści traktatu. Zamiast tego dołączona została Deklaracja Nr 17, która mówi, iż zgodnie z orzecznictwem TSUE prawo unijne oraz traktaty UE mają pierwszeństwo przed prawem krajowym: „[...] zgodnie z utrwalonym orzecznictwem Trybunału Sprawiedliwości Unii Europejskiej traktaty i prawo przyjęte przez Unię na podstawie traktatów mają pierwszeństwo przed prawem państw członkowskich na warunkach ustanowionych przez wspomniane orzecznictwo".

Jak zauważa Stanisław Biernat, status zasady nadrzędności w żaden sposób nie stał się bardziej wyraźny lub czytelny w postlizbońskiej rzeczywistości (Biernat, 2011, s. 48). Sprzeciw grupy państw, który uniemożliwił włączenie regulacji o prymacie prawa europejskiego do porządku traktatowego, przyczynił się paradoksalnie do pomyślnej ratyfikacji całego dokumentu, ale dokonał jednocześnie jego dekonstytucjo-

${ }^{3}$ Negatywnie na temat traktatu lizbońskiego wypowiedziało się społeczeństwo Irlandii. 12 czerwca 2008 r. w referendum padło 53,4\% głosów przeciw traktatowi. Dopiero po udzieleniu Irlandii politycznych i prawnych gwarancji w dziedzinach, które budziły wątpliwości i przyczyniły się do negatywnego wyniku w referendum (polityka podatkowa, ochrona prawa do życia, edukacja i rodzina, polityka neutralności i niektóre kwestie pracownicze i społeczne) podjęto decyzję o drugim referendum, które odbyło się 2 października 2009 roku. Tym razem przy frekwencji 58\% padło 67\% głosów na tak. Wątpliwość budzi fakt powtarzanego referendum i brak poszanowania dla pierwszego wyniku, co pokazuje niespójną postawę wobec reguł demokracji. 
nalizacji (Biernat, 2011, s. 54). Sam traktat, pomimo wysiłku włożonego w proces jego ratyfikacji nie stał się okolicznością sprzyjającą podejmowaniu prób $\mathrm{w}$ dokonywaniu zmian o zasadniczym charakterze, z wyjątkiem pilnej konieczności, wywołanej warunkami trudnymi do przezwyciężenia. Nie ustały obawy państw członkowskich przed wprowadzeniem zasady pierwszeństwa do tekstu traktatów i nie zostały określone tym samym nowe granice rozwoju systemu (Biernat, 2011, s. 57). System stał się mniej przejrzysty z uwagi na rozmyty status jednej z zasadniczych reguł, decydującej o sposobie implementacji porządku prawnego UE do porządków narodowych i tym samym determinującej zakres spójności całego porządku prawnego: „Z jednej strony samodzielny i odrębny charakter zasady pierwszeństwa pozostaje nienaruszony, a nawet ulega wzmocnieniu, jeśli się tę zasadę zakotwicza w traktatach. Oceny tej nie zmienia okoliczność, że zasada ta nie została wyrażona w traktatach bezpośrednio" (Biernat, 2011, s. 59). Nie doszło zatem do wyraźnego przesunięcia w stronę ponadnarodowego porządku prawno-politycznego czy umocnienia międzyrządowości.

Można także wskazać na rozwiązania Traktatu lizbońskiego, których wpływ ugruntował zmiany o istotnym ogólnym charakterze systemowym. Przekształcenie UE w jednolitą organizację międzynarodową pozwala założyć iż kierunkiem rozwoju UE jest pozostanie na ścieżce organizacji międzynarodowej kreowanej na mocy umowy międzynarodowej (Barcz: 2017, s.78). I jakkolwiek dla bieżącego funkcjonowania UE rozwiązanie to nie ma znaczenia praktycznego, to należy zaznaczyć jego ważne implikacje polityczne dla postrzegania charakteru prawnego Unii. Można by natomiast uznać, iż dopełnieniem takiego podejścia byłoby wyraźne zaznaczenie, iż UE jest organizacją międzynarodową o cechach ponadnarodowych. Taki zapis byłby nie tylko zgodny z rzeczywistą naturą UE, ale wprowadzałby tę kluczową dla zrozumienia UE kategorię w prawne ramy traktatowe. Janusz Węc komentując międzypaństwowe założenie ugruntowane przez Traktat lizboński (razem z ustanowieniem sztywnego podziału kompetencji między UE a państwami członkowskimi, wzmocnieniem zasady pomocniczości, zasady ochrony tożsamości i kompetencji Rady Europejskiej), widzi w tym wyznaczenie granic dla rozwoju infrastruktury ponadnarodowej (Węc, 2012, s. 518-519).

W połowie drogi do zdecydowanych i wyraźnych rozwiązań znalazła się także demokracja europejska, rozumiana jako stosowanie demokratycznych mechanizmów w przestrzeni integracyjnej, jak również aprobata dla aksjologii, na której opiera się cały projekt europejski. Demokratyczny wizerunek UE nie jest jednolitym obrazem. Można go raczej porównać do efektu otrzymanego w wyniku przeglądania się w zniekształcającym rzeczywistość lustrze, które nie oddaje do końca prawdy o oglądanym obiekcie. Główną przyczyną zakłóceń, powodujących dysonans w postrzeganiu, ale też samym funkcjonowaniu demokracji w UE jest specyfika środowiska politycznego, w którym wypełniane są reguły demokratycznej gry.

Demokratyczne dylematy procesu integracji można analizować z dwóch punktów widzenia: koncentrując się na niedoskonałościach w funkcjonowaniu i przejawianiu się demokratycznych instytucji i mechanizmów, co generuje zjawisko deficytu demokracji lub poszukując nowej, wyjątkowej dla UE formuły demokracji. Pierwsze z wymienionych podejść obejmuje zabiegi interpretacyjne, które wykazują, iż w UE nastąpiło powierzenie procesu decyzyjnego w ręce przedstawicieli narodowych władz 
wykonawczych, którzy współdziałając z PE, czasem organami doradczymi tworzą prawo obowiązujące potem bezpośrednio w państwach członkowskich. Jednak ci sami decydenci nie są bezpośrednio rozliczani ze swoich działań na poziomie europejskim, co tworzy wyrwę w demokratycznym mechanizmie rozliczalności. Z perspektywy tradycyjnego państwa demokratycznego zaburzony jest mechanizm oparty na trójpodziale władz, co można uznać, za jeden z cięższych grzechów popełniony przeciwko demokratycznemu systemowi politycznemu ${ }^{4}$.

Wśród badań nad specyfiką demokracji w UE dominuje sieciowe i postpolityczne spojrzenie na zjawisko integracji europejskiej, które implikuje mniej jednoznaczne sądy i opinie. Przykładem może być konstatacja: „Byłoby dalece nieprecyzyjne nazywać UE strukturą niedemokratyczną, choć będzie wiele prawdy w twierdzeniu, że jest to podmiot postdemokratyczny w tradycyjnie rozumianym ładzie międzynarodowym" (Młyńczyk, 2005, s. 200).

Z pewnością demokracja na poziomie europejskim nie stanowi odzwierciedlenia reguł demokratycznych kształtowanych przez wieki w obrębie wspólnot państwowych. Czy może mamy zatem do czynienia, jak sugerują Hagen Schulz-Forberg i Bo Strath, z hipokryzją w odniesieniu do debaty na temat demokratycznego wymiaru integracji europejskiej? Czy nie poruszamy się raczej w obrębie kolejnego trójkąta, którego wierzchołkami i punktami odniesienia w analizie UE jednocześnie są krytyka - kryzys - hipokryzja? (Schulz-Forberg, Strath, 2012, p. 3). Jak podkreślają wymienieni badacze, idea demokratyzacji przez budowanie rynku jest oparta na pozbawionym historycznego poparcia myśleniu, na temat pojawienia się demokracji w Europie. Tym, co zaważyło na europejskiej demokratyzacji były konflikty społeczne i oddolne procesy prowadzące do protestów, na które następnie próbowano znaleźć odpowiedź, nie zaś próby urynkowienia gospodarek ${ }^{5}$.

Traktat lizboński nie zmienił w sposób znaczący tego stanu rzeczy, nie wzmocnił mechanizmów usprawniających realizację demokratycznych zasad i wartości, nie spełniając tym samym obietnicy przywódców UE, którzy deklarując, iż nowy traktat uczyni UE bardziej demokratyczną, bardziej przejrzystą i efektywną i wzmocni legitymację UE w oczach obywateli. Deklaracja z Laeken poprzedzająca proces zmian procesu integracji oznajmiała, iż Unia Europejska wywodzi swoją legitymację, cele, uprawnienia i instrumenty z wartości i instytucji demokratycznych: „Unia musi stać się bardziej demokratyczna, bardziej przejrzysta i wydajniejsza. Musi także rozwiązać trzy podstawowe wyzwania: jak przybliżyć obywateli, a przede wszystkim młodzież, do europejskiego wzorca i instytucji europejskich, jak zorganizować politykę i europejski obszar polityczny w rozszerzonej Unii oraz jak przekształcić Unię w czynnik stabilizujący i model w nowym, wielobiegunowym świecie. Konieczne jest zatem postawienie szeregu szczegółowych pytań" (Laeken Declaration on the Future of the European Union) ${ }^{6}$.

${ }^{4}$ Fragment pochodzi z testu Disamantling of the Spitzenkandidaten mechanism after the 2019 European elections - failure of EU democracy or political pragmatism? będącego w procesie recenzji do czasopisma „Online Journal Modelling the New Europe”.

${ }^{5}$ Ibidem.

${ }^{6}$ Laeken Declaration on the Future of the European Union, Bulletin of the European Union. Presidency Conclusions of the Laeken European Council (14 and 15 December 2001), Office for Official Publications of the European Communities, Luxembourg, s. 19-23. 
Czy traktat lizboński zdołał osiągnąć tak wzniosłe cele, zwłaszcza te odnoszące się do instytucji? Szereg modyfikacji wprowadzonych przepisami traktatu z pozoru niosło pokaźny potencjał demokratyzujący. Rozszerzenie zakresu głosowania większością kwalifikowaną do ponad czterdziestu obszarów, wzmocnienie kompetencji Parlamentu Europejskiego i parlamentów narodowych, ustanowienie nowego instrumentu demokracji bezpośredniej w postaci Europejskiej Inicjatywy Obywatelskiej (EIO) czy pełna instytucjonalizacja Rady Europejskiej, to najważniejsze zmiany o demokratycznym charakterze i jednocześnie niskiej skuteczności (Södersten i in., 2019). Wprawdzie niektóre z nich mocniej niż inne przyczyniły się do zwiększenia efektywności funkcjonowania systemu integracyjnego, jak wspomniane umocnienie prerogatyw Parlamentu Europejskiego ${ }^{7}$, to jednak pomimo wszystkich reform (także tych pośrednio związanych z procesem demokratyzacji UE) w ciągu dekady od ratyfikacji Lizbony, UE ogólnie stała się mniej demokratyczna i mniej wydajna.

Szczególnie rozczarowujący może wydać się sposób wykorzystania jedynego instrumentu demokracji bezpośredniej wprowadzonego pod nazwą Europejskiej Inicjatywy Europejskiej, który w Traktacie o UE (wersja traktatu z Lizbony) ${ }^{8}$ jest opisany w sposób następujący: „obywatele Unii w liczbie nie mniejszej niż milion, mający obywatelstwo znacznej liczby Państw Członkowskich, mogą podjąć inicjatywę zwrócenia się do Komisji Europejskiej o przedłożenie, w ramach jej uprawnień, odpowiedniego wniosku w sprawach, w odniesieniu do których, zdaniem obywateli, stosowanie Traktatów wymaga aktu prawnego Unii” (TUE, art. 11 ust. 4).

Ograniczenia w stosowaniu tego narzędzia, a tym samym bariery w oddziaływaniu jego demokratycznego potencjału, wynikają z wielu źródeł, począwszy od złożonej procedury zgłaszania wniosków, po uwarunkowania wewnętrzne samego procesu integracji. Procedura uwzględnia kilka stopni, zaczynając od zawiązania komitetu obywatelskiego, rejestracji inicjatywy przez Komisję Europejską, poprzez etap zbierania deklaracji poparcia, weryfikację i certyfikację zebranych podpisów aż po ostateczne przedłożenie i rozpatrzenie wniosku. Cały proces zajmuje ponad 1,5 roku, co już poddaje pod wątpliwość samą skuteczność przedsięwzięcia. Nowe regulacje prawne, które weszły w życie w styczniu 2020 r. nie zmieniły w sposób widoczny tego stanu rzeczy. Założeniem legislatorów europejskich było uproszczenie procedury. Nowe prawo

${ }^{7}$ Parlament Europejski zyskał na swoich uprawnieniach poprzez rozszerzenie stosowania większością kwalifikowaną, w której PE ma znaczącą rolę oraz w sposób istotny wzmocnienie pozycji Parlamentu w procedurze budżetowej.

${ }^{8}$ Traktat o Unii Europejskiej, Dz. Urz. UE C 326 z dnia 26 października 2012 r.

9 Szczegółowe regulacje dotyczące inicjatywy zgodnie z art. 24 Traktatu o funkcjonowaniu Unii Europejskiej (TFUE), zostały przedstawione w drodze rozporządzenia Parlamentu Europejskiego i Rady (UE) w sprawie inicjatywy obywatelskiej (Rozporządzenie 211/2011). Rozporządzenie weszło w życie 1 kwietnia 2012 r. Zostało ono zastąpione rozporządzeniem UE nr 2019/788), które obowiązuje od 1 stycznia $2020 \mathrm{r}$. Modyfikacja wynikała z licznych uwag wskazujących na konieczność zmian w procedurze. W efekcie 13 września 2017 r. Komisja przedstawiła wniosek ustawodawczy w sprawie przeglądu europejskiej inicjatywy obywatelskiej. W wyniku negocjacji międzyinstytucjonalnych prowadzonych od września do grudnia 2018 r. Parlament i Rada, w dniu 12 grudnia 2018 r., osiągnęły porozumienie polityczne. Na uzgodniony tekst Parlament Europejski wyraził zgodę 12 marca 2019 r., a Rada - 9 kwietnia. Akt końcowy podpisano 17 kwietnia, a 17 maja 2019 r. opublikowano go w Dzienniku Urzędowym Unii Europejskiej (Dz. U. L 130). 
pozostawiło wymóg rozpatrzenia przez Komisję, w ciągu 12 miesięcy wniosku podpisanego przez milion obywateli. Umożliwiono natomiast obywatelom UE poparcie dowolnej inicjatywy bez względu na miejsce zamieszkania i wprowadzono większą elastyczność w wyborze daty rozpoczynającej zbieranie podpisów (w ciągu sześciu miesięcy od rejestracji) oraz uproszczono wymogi dotyczące danych osobowych. Ważnym jest wprowadzenie centralnego systemu online służącego do zbierania podpisów i zastąpienia nim do 2022 r. systemów stosowanych w poszczególnych państwach. $\mathrm{Na}$ wyraźne żądanie Parlamentu Europejskiego nowe rozporządzenie przewiduje również większe wsparcie dla organizatorów europejskiej inicjatywy obywatelskiej w postaci punktów kontaktowych w każdym państwie członkowskim i internetową platformę współpracy. Nie bez znaczenia jest fakt, iż z trzech do sześciu miesięcy skrócono okres, w którym Komisja ma obowiązek ustosunkować się do prawidłowo zarejestrowanej inicjatywy.

Czy są to jednak zasadnicze zmiany, które mogłyby zaradzić realnym słabościom tego instrumentu demokracji bezpośredniej? Czy modyfikacji uległ fakt, iż większość inicjatyw nie dociera do etapu traktowanego jako sukces? (statystyki pokazują, iż od momentu wejścia w życie pierwszego rozporządzenia w 2011 roku do chwili obecnej (stan na luty 2021) złożonych zostało 99 wniosków o rejestracje, z czego zarejestrowano 76 a sukcesem zakończyło 6). Problemy w wykorzystaniu mechanizmu są związane także $\mathrm{z}$ brakiem wyraźnych wytycznych co do zakresu materialnego możliwego do zastosowania. Jako, że inicjatywa może być zastosowana tylko w przypadku spraw objętych całkowitą kompetencją UE, błędne jej wykorzystanie jest związane właśnie $\mathrm{z}$ nieprawidłową oceną sytuacji w tym kontekście, zwłaszcza, że drugim kryterium jest tutaj obecność inicjatywy ustawodawczej Komisji. Jak zauważa Jan Barcz oznacza to, że zakres dziedzin, w których jest możliwe podejmowanie inicjatywy obywatelskiej, jest węższy niż zakres kompetencji Unii Europejskiej (Barcz, 2011, s. 20-21; za: Zdanowicz, 2018, s. 109). W sytuacji braku wypełnienia tego kryterium Komisja odmawia rejestracji inicjatywy. I jakkolwiek nowe rozporządzenie zapewnia wsparcie dla organizatorów przedsięwzięcia, to jednak nie można oprzeć się wrażeniu, iż podjęto decyzję o stworzeniu możliwości włączenia w trudny proces legislacyjny UE samych obywateli, bez stworzenia mechanizmów ich merytorycznego wsparcia (Zdanowicz, 2018, s. 112). Wydaje się, że wprowadzone zmiany nie wpłynęły bezpośrednio na zwiększenie efektywności inicjatywy jako narzędzia demokracji bezpośredniej w UE (Parol, 2020, s. 88). Tym samym nie nastąpiło znaczące wzmocnienie zapisu Traktatu lizbońskiego i granice jego demokratycznego oddziaływania nie uległy przesunięciu.

Opisany przykład odzwierciedla pewną tendencję procesu integracyjnego, polegającą na tworzeniu rozwiązań o połowicznym efekcie oddziaływania. Traktat lizboński nie stanowi przełomu w tym względzie. Poza EIO można wskazać chociażby na rozwiązania w odniesieniu do polityki zagranicznej. Formalnie regulacje odnoszące się do tych kwestii zostały, w wyniku likwidacji filarów, włączone do treści Traktatu o UE i Traktatu o funkcjonowaniu UE, co sugerowałoby rozciągnięcie metody wspólnotowej na obszar polityki zagranicznej. Tak się jednak nie stało. Polityka zagraniczna pozostała pod wpływem odmiennego, stricte międzyrządowego reżimu prawnego. Jak zauważa Kamil Zajączkowski: „[...] same postanowienia lizbońskie nie rozwiązują problemu efektywności zewnętrznego wymiaru aktywności Unii Europejskiej. Pierw- 
sze lata funkcjonowania WPZIB i WPBiO w ramach TL ukazują liczne wyzwania, ograniczenia i słabości w tym zakresie" (Zajączkowski, 2014, s. 12). Nawet jeżeli weźmiemy pod uwagę fakt, iż realizacja tej polityki w dużym stopniu zależy od woli politycznej państw członkowskich i należy do tzw. wrażliwych obszarów integracyjnych, to jednak wykreowanie pewnych rozwiązań instytucjonalnych nie wpłynęło pozytywnie na osiąganie większej skuteczności w tym obszarze funkcjonowania UE. Chodzi m.in. o hybrydowe rozwiązania instytucjonalne takie jak umocowanie prawne Wysokiego Przedstawiciela Unii Europejskiej do spraw Zagranicznych i Polityki Bezpieczeństwa (WP) ${ }^{10}$ czy Europejskiej Służby Działań Zewnętrznych.

Dlatego też trudno się nie zgodzić ze stwierdzeniem, że z punktu widzenia demokratyzacji procesu integracji, być może ważniejsze od tego, czego dokonał traktat lizboński, jest to, czego nie uczynił. Wprowadzając szereg reform mających na celu rozwiązanie wyolbrzymionych często problemów, nie przewidział i nie rozwiązał tego, co w rzeczywistości stanowiło najpoważniejsze zagrożenia dla demokracji i wydajności w UE. (Kelemen, 2019, s. 2016). Traktat z Lizbony nie uzdrowił demokratycznej natury UE, nie zaproponował nowych (być może poza Europejską Inicjatywą Obywatelską) rozwiązań, dzięki którym nastąpiłoby przeformułowanie w funkcjonowaniu mechanizmów demokratycznych w przestrzeni UE. Dobudował jedynie pewne instrumenty lub wzmocnił już istniejące mechanizmy, które jednak bez wystarczającej woli politycznej państw członkowskich i sprzyjających uwarunkowań wynikających z systemu integracyjnego, nie wpłynęły na redukcję deficytu demokracji w UE. Podążając za tym wątkiem, uzasadnionym i inspirującym może się okazać wniosek, iż główne deficyty demokratyczne w UE wynikają nie z poziomu UE, ale z demokratycznego regresu wśród rządów państw członkowskich (Kelemen, 2019, s. 57).

Poza samymi zapisami traktatowi wynikającymi z litery prawa pod uwagę należy wziąć także rzeczywistość, która towarzyszyła ich wprowadzaniu. Kryzys w strefie euro i kolejne kryzysy następujące po nim sprawiły, że Europejscy przywódcy poszukując odpowiedzi na pojawiające się trudności, przekazali UE szereg nowych uprawnień w dziedzinie regulacji bankowych i nadzoru podatkowego. Pod pewnymi względami wzmocniło to samą UE, jednak demokracja procesu integracji stanęła przed kolejnymi wyzwaniami. W sposób szczególny została ona osłabiona wraz $\mathrm{z}$ pojawieniem się $\mathrm{w}$ niektórych państwach tendencji autorytarnych oraz wzmocnieniu procesów międzyrządowych uwidocznionych w decyzjach podejmowanych przez Radę Europejską (Kelemen, 2019, s. 56) ${ }^{11}$. Jak zauważa Danuta Kabat-Rudnicka: „Cechą charakterystyczną działań antykryzysowych podejmowanych przez UE jest to, że prowadzone były, co do zasady, poza ramami traktatowymi i nie pociągały za sobą większej zmiany traktatowej. Początkowo posiłkowano się formą umów międzypaństwowych, następnie zaś podejmowano wspólne działania, które nie ograniczały się wyłącznie do państw strefy euro, lecz były (i nadal są) otwarte dla państw spoza strefy. Działania te generują zmiany, nie pozostając bez wpływu zarówno na równowagę, jak i na kształtowanie się nowej architektury instytucjonalnej” (Kabat-Rudnicka,

${ }_{10}$ Więcej na ten temat w dalszej części tekstu.

${ }^{11}$ Nowa pozycja Rady Europejskiej zapisana w traktacie z Lizbony szybko została wykorzystana w kryzysowej rzeczywistości. Rada Europejska stała się jednym z głównych graczy w tworzeniu nowych narzędzi w walce z kryzysem. Więcej na ten temat: Fabbrini, 2016. 
2016, s. 71-72). Według Schimmelfennig nastąpił „duży skok ponadnarodowy i technokratyczny" (Schimmelfennig, 2014, s. 323). Z kolei Bickerton i inni twierdzą, że tylko traktat fiskalny w pewnym stopniu ulegitymizował Komisję Europejską, a unia bankowa silniej umocowała tylko Europejski Bank Centralny. Z kolei Rada uniknęła przekazania swoich kompetencji Komisji poprzez tworzenie organów de novo, jak w przypadku Europejskiego Mechanizmu Stabilności (ESM), poddanego jej kontroli (Bickerton i in., 2015).

Dokonując generalizacji rozważań dotyczących wpływu traktatu z Lizbony na system polityczny UE można stwierdzić, iż nie doszło do wyraźnego przesunięcia granicy na kontinuum rozwoju procesu integracji europejskiej. Adrian Schout i Sarah Wolff zauważają istnienie ,paradoksu Lizbony”, który polega na dezorientacji i zamieszaniu co do kierunku integracji. Piszą oni: „Lizbona rozpoczęła się jako wzmocnienie ponadnarodowości (Konstytucja), ale wydaje się, iż doszło do umocnienia międzyrządowości. Nowe funkcje, takie jak Wysokiego Przedstawiciela Unii ds. Zagranicznych i Polityki Bezpieczeństwa, Przewodniczącego Rady Europejskiej czy formalizacja Rady Europejskiej jako instytucji wzmacniają według niektórych międzyrządową stronę UE" (Schout, Wolff, 2012, s. 21). Postlizbońska rzeczywistość pozostała niedopowiedziana i pozostawiła system w swoistym zawieszeniu pomiędzy dwoma porządkami: międzynarodowym i quasi państwowym. Jak ujmuje to Ingolf Pernice, refleksja nad traktatem lizbońskim może oznaczać odmienne konstatacje dla różnych badaczy. Dla jednych to niekończąca się rozmowa o historii niepowodzeń w reformowaniu UE i poszukiwań dla niej konstytucyjnej formuły. Inni, w mniej optymistycznym ujęciu, będą w tym widzieli kolejną próbę w dążeniach rządów państw członkowskich do przełamywania demokratycznych decyzji narodów europejskich. Wreszcie, czego zwolennikiem jest sam cytowany autor, traktat lizboński można postrzegać jako jeden z wielu etapów niezwykle złożonego procesu tworzenia konstytucji dla instytucji politycznej, której charakter nie pasuje do żadnej ze znanych kategorii politycznych (Pernice, 2009, s. 351). Pomimo znaczenia instytucjonalnego i wprowadzonych reform o znaczeniu konstytucyjnym, traktat lizboński to tylko kolejny dokument o znaczeniu konstytucyjnym, a nie formalna konstytucja, która określiłaby granice rozwoju systemu na kolejne dekady. Jego spuścizną jest złożony system integracyjny, oparty na mechanizmie nieustannego pokonywania kryzysów i poszukiwania rozwiązań adaptacyjnych do zmieniającej się rzeczywistości.

\section{Unia Europejska jako wspólnota instytucjonalna w postlizbońskiej rzeczywistości integracyjnej}

Płaszczyzna instytucjonalna jako jedna z wielu platform współpracy integracyjnej ogniskuje w sobie trudności i zawiłości całego procesu. Instytucje UE tworzą niepowtarzalny system powiązań kompetencji, ludzi i funkcji. Ich aktywność odbywa się w środowisku powiązań sieciowych, co pozwala instytucjom wymieniać się władzą i zakresem odpowiedzialności w różnych dziedzinach polityki integracyjnej, jak też na różnych etapach procesu decyzyjnego UE (Hix, 1998, s. 38-65). Sieciowość układu ma postać niedomkniętą, ponieważ zasadniczą kwestią jest jego permanentne ,adaptowanie się" (Rothert, 2010, s. 46). Nie pozwala to na osiągnięcie względnie stałego 
stanu rozwoju przez system instytucjonalny, który podlega nieustannym modyfikacjom wymuszonym przez konieczność adaptowania się do zmian. Cała europejska przestrzeń polityczna jest nakierowana na modernizowanie, jednak jej immanentne właściwości sprawiają, iż jest to proces, który przebiega w sposób trudny do przewidzenia. W dużym stopniu decydują o tym szczególne rozwiązania instytucjonalne.

Rzeczywistość instytucjonalna wynikająca z ustaleń traktatu z Lizbony oraz pokryzysowych posunięć nie uprościła funkcjonowania całego systemu. Jak wspomina Młyńczyk: „Obiektywny brak możliwości wyjaśnienia specyfiki instytucji in statu nascendi zachęcał do ucieczki do przodu, tak aby przez przypisywanie cech niespecyficznych, starać się dla odmiany zrozumieć funkcjonowanie samej UE” (Młyńczyk, 2005, s. 199).

System UE charakteryzuje głęboka złożoność funkcjonalna, która nie powinna być jednak traktowana jako jedna $\mathrm{z}$ wielu cech procesu integracji europejskiej. Jest to raczej jego fundamentalna właściwość wynikająca z konieczności łączenia wielu poziomów współpracy. System oparty jest na stałym napięciu pomiędzy interesem wspólnotowym a partykularnymi interesami narodowymi. Ta pierwotna sprzeczność zostaje następnie przeniesiona na poszczególne układy systemu, nadając mu charakter złożonej sprzeczności. Dysonans i brak harmonii kumulują się także na gruncie podziału władzy i to niezależnie od etapu rozwoju procesu integracyjnego: Rada i Komisja regularnie toczą spory w kwestii podziału władzy wykonawczej, Parlament Europejski ściera się z Komisją a parlamenty narodowe czują się wyobcowane z Unii i mają pretensje o rolę Parlamentu Europejskiego w procesie podejmowania decyzji (Wierzchowska, 2020, s. 783, za: Leonard, 2000, s. 42).

Traktat z Lizbony nie uprościł reguł funkcjonowania systemu politycznego UE. Pomimo zniesienia budowy filarowej nie doszło do wyraźnego uproszczenia struktury $\mathrm{w}$ aspekcie funkcjonalnym. Powstały nowe rozwiązania instytucjonalne, które wpisując się w architekturę istniejących organów wpłynęły na przesunięcia kompetencyjne. Polityczna ocena efektów wynikających z samych zapisów traktatowych z pewnością będzie się różnić od komentarzy specjalistów i badaczy z zakresu procesów integracyjnych. Jose Manuel Barosso niezwykle optymistycznie ocenił rozwiązania lizbońskie stwierdzając: „Traktat lizboński wzmacnia projekt europejski. To wzmacnia instytucje europejskie - wszystkie instytucje. Zapewnia większą spójność, skuteczność i zasadność naszych decyzji” (Barosso, 2011, s. 11). Ta bardzo optymistyczna, ogólna wizja jest interpretowana w nieco inny sposób przez ekspertów, którzy przedstawiają bardziej wnikliwą i merytoryczną ocenę stanu rzeczy. Jorg Monar w swojej analizie dotyczącej zmian w mechanizmach równowagi instytucjonalnej przeprowadzonej w 2011 roku proponuje zastosowanie sześciowymiarowego instrumentu badawczego, pozwalającego ocenić przesunięcia w zakresie badanego zjawiska. Składają się na nie: konstytucyjna pozycja każdej z instytucji, władza w zakresie inicjowania polityk, siła wpływu w procesie decyzyjnym, zakres udziału w implementacji rozwiązań, zakres samodzielności w określaniu wewnątrzinstytucjonalnej organizacji oraz uwidocznienie zmian i ich odbiór publiczny. Dokonując szczegółowej analizy w zakresie wszystkich tych zmiennych w odniesieniu do głównych instytucji autor dochodzi do wniosku, iż: „Europejski Parlament i Rada Europejska mają po pięć „plusów” i jednym „zerze”, jako główni i w rzeczywistości najważniejsi beneficjenci reform traktatu lizbońskiego, podczas gdy Komisja Euro- 
pejska z czterema „minusami” i dwoma „plusami” oraz Rada z czterema „zerami” i dwoma ,minusami” wyłaniają się jako wyraźni przegrani nowego salda instytucjonalnego" (Monar, 2011, s. 85).

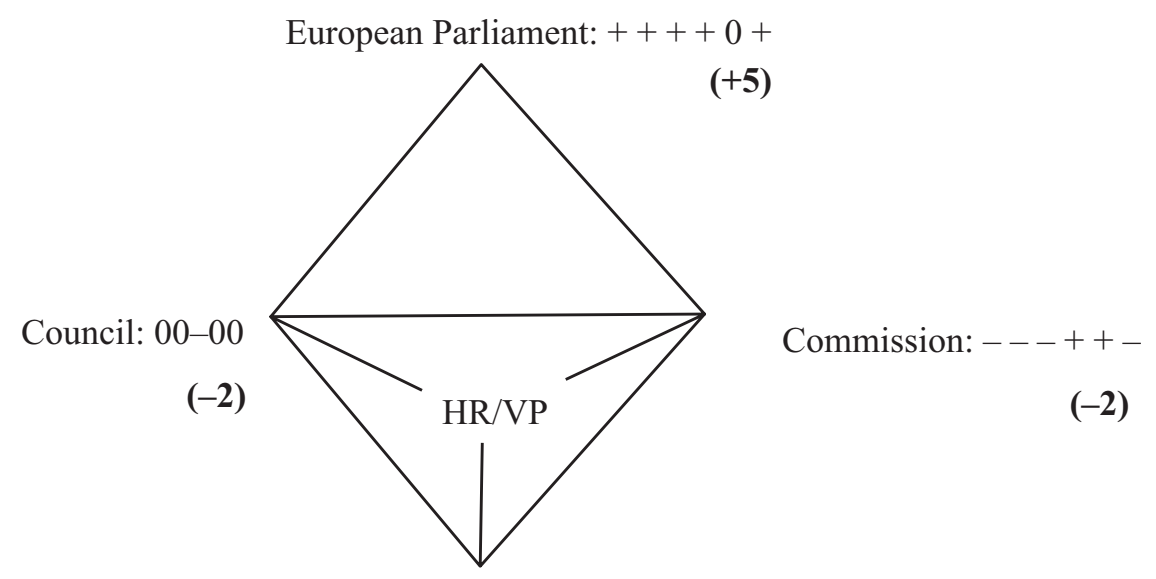

European Council: $+++0++$

Rys. 1: Postlizbońska równowaga instytucjonalna

Źródlo: Monar, 2011, s. 86.

Komentując swoje badanie Monar konkluduje, iż w efekcie to Parlament Europejski i Rada Europejska wyłaniają się jako główne bieguny władzy w postlizbońskim porządku instytucjonalnym. Oznacza to, że dalsza ewolucja Unii, szczególnie w zakresie jej ram konstytucyjnych i polityk będzie bardziej niż kiedykolwiek zależeć od stanu relacji między tymi dwiema instytucjami, w tym zgodności co do wyznaczanych celów priorytetowych. W związku z tym istnieje potrzeba rozwijania współpracy między Parlamentem i Radą Europejską, co może być tym trudniejsze w sensie formalnym, iż zakres wspólnych działań obu instytucji jest najsłabiej zdefiniowanym spośród innych organów w traktacie z Lizbony (Monar, 2011, s. 86).

Ważną modyfikacją z punktu widzenia zmian w ładzie instytucjonalnym stało się również wprowadzenie nowej formuły dla Wysokiego Przedstawiciela. Wyznaczany przez Radę Europejską i biorący udział w jej pracach w odniesieniu do określania priorytetów w ramach polityki zagranicznej i bezpieczeństwa, mandat uzyskuje od Rady i bierze udział w jej pracach w ramach formacji Rady ds. Zagranicznych. Jednocześnie Wysoki Przedstawiciel jest Wiceprzewodniczącym Komisji Europejskiej i odpowiada za kwestie polityki zewnętrznej. W ten sposób traktat lizboński przypisał Wysokiemu Przedstawicielowi pozycję gdzieś pośrodku układu, między pod-trójkątem instytucjonalnym Rady, Parlamentu Europejskiego i Komisji, a poprzez dodanie Rady Europejskiej wykreował czworokąt decyzyjny (Monar, 2011, s. 88) ${ }^{12}$.

${ }^{12}$ Fragment pochodzi z oddanego do publikacji tekstu: Unia Europejska jako wspólnota instytucjonalna. 
Tradycyjnie interpretacja zmian $w$ mechanizmach instytucjonalnych jest również podejmowana przy wykorzystaniu kategorii międzyrządowości i ponadnarodowości. Godzenie tych dwóch porządków wynika z funkcjonowania wielopoziomowego sytemu zarządzania w systemie integracyjnym. Nie zawsze było (i jest) to jednak współistnienie oparte na bezkolizyjnej współpracy. Desmond Dinan zauważa: „Napięcie pomiędzy międzyrządowością (tradycyjne relacje międzypaństwowe) a ponadnarodowością (dzielenie suwerenności narodowej) przenika UE od samego początku. Jednak międzyrządowość i ponadnarodowość nie są sprzecznymi pojęciami, uzupełniają się raczej niż stoją w sprzeczności ze sobą w bieżącej aktywności UE. Ta relacja nie jest statyczna" (Dinan, 2005, s. 2). Jej efektem jest potrzeba godzenia dwóch logik politycznego decydowania: ponadnarodowej i międzyrządowej i wymusza rozwój mechanizmu ich szczególnego równoważenia. Ta swoista kooperacyjno-rywalizacyjna natura prowadzi do nasilania się konfliktów tak samo jak zachowań solidarnych.

Traktat lizboński w sposób dla siebie specyficzny reformuje tę ponadnarodową i międzyrządową kategoryzację. Wprowadzone modyfikacje wydają się świadczyć, iż rozróżnienie pomiędzy elementami ponadnarodowymi i międzyrządowymi zostało częściowo osłabione i stały się są trudne do zastosowania do rzeczywistości instytucjonalnej. Świadczy o tym chociażby nowa pozycja Rady Europejskiej, która od początku swojego istnienia była jednym z najsilniejszych przejawów międzyrządowości. Jednak traktat z Lizbony nie wzmacnia tego stanu rzeczy. Rada Europejska stała się pełnoprawną instytucją Unii Europejskiej, podlegającą jurysdykcji Trybunału Sprawiedliwości. Pomimo, że nadal reprezentuje interesy państw członkowskich jej międzyrządowa natura została naruszona (Monar, 2011, s. 88). Stąd coraz częściej dla określenia relacji pomiędzy tymi dwoma reżimami: ponadnarodowym i międzyrządowym używany jest termin ponadnarodowa międzyrządowość.

Postlizboński porządek instytucjonalny nie zawiera się jednak tylko w analizie zapisów traktatowych czy spojrzeniu na pierwsze lata funkcjonowania UE w nowym reżimie prawnym. Także konieczność wprowadzenia niezbędnych kroków ratowniczych w trakcie kryzysu strefy euro wpłynęła na kolejne komplikacje w i tak już złożonym obrazie rzeczywistości instytucjonalnej. Szereg działań instytucjonalnych podjętych po 2008 roku oznaczało bowiem przekroczenie przewidzianych w traktatach kompetencji. Przykładem jest proces dochodzenia do Europejskiego Mechanizmu Stabilności (EMS): „To oczywiste, że tworząc stały mechanizm stabilności, Rada Europejska oraz kraje członkowskie stanęły przed poważną przeszkodą natury prawnej. Jak bowiem ustanowić fundusz pomocy polegającej na przejęciu zobowiązań, kiedy wszystko wskazuje na to, że jest to wyraźnie zakazane w traktatach unijnych?" (Tomkin, 2013, s. 274-275).

$\mathrm{Z}$ punktu widzenia prawnego, ustanowienie ESM poza unijnym porządkiem prawnym, według części prawników, nie da się pogodzić z wieloma zasadami prawa europejskiego, jak chociażby zasadą nadrzędności i lojalnej współpracy ${ }^{13}$. Także zasada równowagi instytucjonalnej, która organizuje współdziałanie instytucji europejskich w przestrzeni decyzyjnej i politycznej UE z uwzględnieniem obowiązującej podstawy traktatowej uległa specyficznej redefinicji. Jak podkreśla Kabat-Rudnicka: „Unia

${ }^{13}$ Fragment pochodzi z oddanego do publikacji tekstu: Unia Europejska jako wspólnota instytucjonalna. 
dzięki podejmowanym w kryzysie działaniom potrafiła nadać nowego znaczenia już istniejącym mechanizmom. Zasadniczo zachowany został układ instytucjonalny, przy czym KE uzyskała nowe kompetencje wykonawcze i monitorujące, wzmocnieniu uległa pozycja RE kosztem Rady ds. Ogólnych, wzmocniona została też pozycja PE, zwiększeniu uległy również kompetencje EBC. Natomiast głosy krytyki kierowane są przede wszystkim pod adresem EBC, niezależnej instytucji, niepoddanej mechanizmowi legitymizującemu, oraz systemu „trojki” (EBC, IMF, KE) formułującej warunki dla państw zagrożonych upadłością, która także nie dysponuje wbudowanym mechanizmem legitymizującym" (Kabat-Rudnicka, 2016, s. 88). Równowaga międzyinstytucjonalna uległa poważnemu naruszeniu.

Ogólna ocena oddziaływań instytucjonalnych w trakcie kryzysu finansowego nie jest jednoznaczna, ale $\mathrm{z}$ pewnością $\mathrm{w}$ dużym stopniu nastąpiło odejście w kierunku międzyrządowym. Jak argumentuje Szczerski: „Fenomen ten polega na wytwarzaniu się nowych ponadnarodowych struktur, wpływających na działania państw członkowskich, nie - jak to dotąd bywało - wokół Komisji Europejskiej i jej agend, ale wokół Rady Europejskiej, w której decydujący głos mają najsilniejsze państwa Unii. Tym samym, to owe najsilniejsze państwa przejmują władzę dyscyplinującą i władzę inicjującą w Unii, zagarniając pole ponadnarodowe. Przykładem najbardziej czytelnym jest tu Pakt Euro Plus, który ma właśnie taki charakter" (Szczerski, 2011, s. 55).

W świetle przedstawionych powyżej opinii i stanowisk trudno nie zgodzić się ze stwierdzeniem, iż rozwój UE po 2005 roku, jakkolwiek pełen napięć tworzy pewien logiczny ciąg zdarzeń zmierzających $\mathrm{w}$ kierunku pogłębiania złożoności w procesie integracji. Narastające problemy i kolejne kryzysy naruszyły wewnętrzną równowagę systemu, który tracił momentami zdolność do jej odzyskiwania (Wierzchowska, 2016, s. 389).

\section{Konkluzje}

Proces integracji europejskiej rozwija się pokonując kolejne etapy współpracy, a jego rezultatem powinno być osiągnięcie dojrzałej formuły powiązań pomiędzy instytucjami europejskimi nadającymi strukturze trwałość i przechowującymi pamięć systemową, celami wyznaczonymi do realizacji oraz pierwotnymi uczestnikami tego systemu, czyli państwami członkowskimi, które nadają mu sens (Wierzchowska, 2016, s. 397). Nie należy się spodziewać, iż system instytucjonalny zostanie kiedykolwiek określony raz na zawsze. Jest to $\mathrm{w}$ istocie wbrew naturze jakiemukolwiek procesowi. Pytaniem jest natomiast $\mathrm{w}$ jakim kierunku będą postępowały zmiany $\mathrm{i}$ czy będą one przekraczać (i ewentualnie jak często) ustanawiane granice. Te ostatnie mogą ulegać przesuwaniu w sposób nie do końca przewidywalny. Pewne procesy zachodzące w strukturach o tak złożonych uwarunkowaniach, jakie są udziałem procesu integracyjnego, wymykają się spod kontroli jego uczestników. Dotyczy to między innymi zakładanych w traktatach europejskich reform, które pomimo przewidywanego efektu modernizacyjnego często oddziałują w sposób odmienny. Dzieje się tak na skutek wpływu czynników zewnętrznych (sytuacji kryzysowych).

Omawiany traktat lizboński miał być remedium na zaistniały kryzys konstytucyjny i jednocześnie miał wprowadzić UE w kolejny etap współpracy europejskiej. Zało- 
żone zmiany miały w dużej mierze charakter reformatorski, jednak na skutek zjawisk kryzysowych, które wkrótce zmieniły rzeczywistość integracyjną, został on w dużej mierze osłabiony. Należy także zaznaczyć, iż jest pewną utrwaloną cechą procesu integracyjnego jest pozostawianie nierozwiązanych kwestii i swoisty brak zakończenia założonego etapu integracyjnego.

Postawione w tytule pytanie o odporność i złożoność systemu instytucjonalnego to w istocie pytanie o specyfikę instytucjonalnego ładu, który stanowi fundament przetrwania i rozwoju procesu integracji. Instytucje są bowiem miernikiem sukcesu całego systemu.

Specyfiką instytucjonalnej przestrzeni UE jest sposób udziału w niej środowiska narodowego, którego zmienność znacząco modeluje arenę zmagań instytucjonalnych zarówno w domenie działań międzyrządowych, jak i ponadnarodowych. Efektem tych współzależnych działań jest wewnętrzna sprzeczność systemu. Mechanizmy zależności pomiędzy poszczególnymi uczestnikami systemu europejskiego są złożone. Wielość poziomów sprawowania władzy wskazuje na zróżnicowanie ośrodków decyzyjnych, które jednak nie równoważą się w swoich kompetencjach. W praktyce to państwa członkowskie kształtują strukturę, decydują o atrybucji kompetencji i architekturze instytucjonalnej i determinują o przetrwaniu całej wspólnoty (Wierzchowska, 2020, s. 783).

Do podobnego wniosku doszedł Robert Wiszniowski pisząc: „Architektura Unii Europejskiej (UE) jest konstrukcją nad wyraz złożoną, co wynika zarówno z wielowymiarowości występujących tam instytucji, jak i ich wielofunkcyjności. Analizując zatem złożoną «unijną» przestrzeń, należy zwrócić uwagę na struktury organizacyjne, ich wzajemne zależności i powiązania oraz na proces zmian zachodzący w ich obrębie, będący rezultatem negocjacji i ustaleń zawieranych między krajami Unii Europejskiej, które szczególnie w latach ubiegłego stulecia nabrały szybkiego tempa" (Wiszniowski, 2008, s. 17).

Aspekt instytucjonalny w odniesieniu do kontekstu złożoności odgrywa bardzo istotną rolę w ocenie tego zjawiska. Szczególne znaczenie ma fakt, iż ci sami aktorzy występują w procesie politycznym rozgrywanym w przestrzeni integracyjnej w odmiennych rolach, a złożoność współzależności, które występują w systemie europejskim, wykracza poza znane i wyjaśnione reguły na poziomie krajowym (Wierzchowska, 2016, s. 395).

Dotychczasowe zmagania instytucjonalne obserwowane w europejskim systemie politycznym wskazują, iż integracja europejska nadal pozostaje na etapie poszukiwań swojego zakończenia politycznego i struktury instytucjonalnej. Innymi słowy, nastąpiły zmiany w stosunkach międzyinstytucjonalnych UE, ale system nie osiągnął krytycznego momentu, który zawróciłby Unię z ustalonej ścieżki równoważenia ponadnarodowych i międzyrządowych wpływów.

\section{Bibliografia}

Albert D., Kreutzer M., Lechner C. (2015), Resolving the paradox of interdependency and strategic renewal in activity systems, "Academy of Management Review", vol. 40, nr 2.

Barcz J. (2011), Inicjatywa obywatelska - aspekty prawne i instytucjonalne, „Europejski Przegląd Sądowy", nr 10.

Barcz J. (2017), Ustrój lizbońskiej Unii Europejskiej. Podstawy traktatowe, struktura, instytucje i prawo, Piaseczno. 
Barosso J. M. (2011), The European Union after the the Treaty of Lisbon, w: The European Union after the Treaty of Lisbon. Visions of Leading Policy-makers, Academics and Journalists, autor zbiorowy Directorate-General for Education, Youth, Sport and Culture (European Commission) Luxembourg.

Bickerton Ch., Hodson D., Puetter U. (2015), The New Intergovernmentalism: European integration in the Post-Maastricht era, "Journal of Common Market Studies", vol. 53, nr 4.

Biernat S. (2011), Zasada pierwszeństwa prawa unijnego po traktacie z Lizbony, „Gdańskie Studia Prawnicze", vol. 25.

Boal K. B., Schultz P. L. (2007), Storytelling, time, and evolution: The role of strategic leadership in complex adaptive systems, "The Leadership Quarterly", vol. 18.

Borg J. (2012), Is "Multi-Level Governance" a Victim of Conceptual Overstretch?, https://www.e-ir. info/2012/08/27/is-multi-level-governance-a-victim-of-conceptual-overstretch/, 13.08.2020.

Cuyvers A. (2017), The Road to European Integration, w: East African Community Law, red. E. Ugirashebuja, J. E. Ruhangisa, T. Ottervanger, A. Cuyvers, Brill.

Dinan D. (2005), Ever Closer Union: An Introduction to European Integration, Palgrave Macmillan.

Fabbrini S., Puetter U. (2016), Integration without supranationalisation: studying the lead roles of the European Council and the Council in post-Lisbon EU politics, "Journal of European Integration", vol. 38, $\mathrm{nr} 5$.

Jordan A. (2009), The European Union: an evolving system of multi-level governance...or government?, "Policy and Politics", vol. 29, nr 2.

Kabat-Rudnicka D. (2016), Zmiana systemu rzadzenia w Unii Europejskiej w świetle działań antykryzysowych, „Studia Europejskie”, nr 1.

Kelemen D. R. (2019), The Impact of the Lisbon Treaty: From Misdiagnosis to Ineffective Treatment, w: The Lisbon Treaty 10 years on: Success or Failure?, red. A. Södersten, Swedish Institute for European Policy Studies.

Leonard M. (2000), Sposób na Europę. Pomiędzy federalizmem a Europa narodów, Warszawa.

Marks G., Hooghe L. (1996), European Integration from the 1980s: State Centric v. Multi-level Governance, "Journal of Common Market Studies", vol. 34, nr 3.

Mieńkowska R. (2013), Wielopoziomowe rzadzenie w przestrzeni ponadnarodowej-charakterystyka w kontekście globalizacji i europeizacji, „Studia Politologiczne”, vol. 27.

Młyńczyk Ł. (2005), „Zarządzanie ryzykiem opuszczania pociagu w trakcie biegu”- jeszcze bardziej polityczna integracja czy dezintegracja europejska?, „Studia Europejskie”, nr 2.

Monar J. (2011), The European Union's institutional balance of power after the Treaty of Lisbon, w: The European Union after the Treaty of Lisbon. Visions of Leading Policy-makers, Academics and Journalists, autor zbiorowy Directorate-General for Education, Youth, Sport and Culture (European Commission) Luxembourg.

Nugent N. (2012), Unia Europejska. Władza i polityka, Wydawnictwo Uniwersytetu Jagiellońskiego, Kraków.

Parol A. (2020), The European Citizens' Initiative Reform: Does it matter?, "Review of European and Comparative Law", vol. XL.

Pernice I. (2009), The Treaty of Lisbon: multilevel constitutionalism in action, "Columbia Journal of European Law", vol. 15.

Rothert A. (2010), Dezagregacja polityki, Warszawa.

Rothert A. (2017), Odporność i szok. Polityka rlewolucji, Scholar.

Schout A., Wolff S. (2012), The „Paradox of Lisbon”: Supranationalizm-Intergovernmentalism as an Administrative Concept, w: The EU's Lisbon Treaty. Institutional Choices and Implementation, red. F. Laursen, Ashgate Publishing Limited. 
Schimmeleninng F. (2014), European Integration in the Euro Crisis: The Limits of Postfunctionalism, "Journal of European Integration", vol. 36, nr 3.

Södersten A. (red.) (2019), The Lisbon Treaty 10 years on: Success or Failure?, Swedish Institute for European Policy Studies.

Stein M., Turkewitsch L. (2010), Multilevel Governance and Federalism: Closely Linked or Incompatible Concepts, „Participation Bulletin of the International Political Science Association”, vol. 34, nr 2 - October/Octobre.

Szczerski K. (2011), Unia Europejska jako polityczny oksymoron. Wewnętrzne sprzeczności integracji: siła czy stabość?, w: Unia Europejska. Dylematy XXI wieku, red. A. Kukliński, J. Woźniak, Kraków; publikacja stanowi pokłosie ogólnopolskiej Czwartej Konferencji Krakowskiej „Unia Europejska. Dylematy XXI wieku”, która odbyła się w Krakowie w dniach 13-14 czerwca $2011 \mathrm{r}$.

Tomkin J. (2013), Wpływ przyjęcia traktatu o Europejskim Mechanizmie Stabilności na stan europejskiej demokracji: sprzeczności wewnętrzne, obchodzenie prawa i gimnastyka pojęciowa, „Nowa Europa. Przegląd Natoliński”, vol. 16, nr 3.

Węc J. (2012), Spór o ksztalt ustrojowy Wspólnot Europejskich i Unii Europejskiej w latach 19502010, Kraków.

Wierzchowska A. (2016), Wpływ modernizacji i kryzysu na dynamikę zmiany w Unii Europejskiej, Elipsa, Warszawa.

Wierzchowska A. (2017), The European Union in search of systemic balance. An analysis involving the concept of resilience, „Przegląd Europejski”, vol. 46, nr 4.

Wierzchowska A. (2020), Complexity of the European Union System and its Adaptation Abilities, "International Journal of Innovation, Creativity and Change", vol. 13, nr 5.

Wiszniowski R. (2008), Europejska przestrzeń polityczna. Zachowania elektoratu w wyborach do Parlamentu Europejskiego, Wydawnictwo Uniwersytetu Wrocławskiego, Wrocław.

Zajączkowski K. (2014), O brakach i niedostatkach w polityce zagranicznej UE, „Studia Europejskie", nr 3.

Zdanowicz M. (2018), Europejska inicjatywa obywatelska. Nieefektywnie wykorzystane pokłady społecznej aktywności, „Przegląd Europejski”, nr 2.

\section{Akty prawne:}

Traktat z Lizbony zmieniający Traktat o Unii Europejskiej i Traktat ustanawiający Wspólnotę Europejska, Dz. U. C 306 z 17.12.2007.

Traktat o funkcjonowaniu Unii Europejskiej, Dz. Urz. UE C 326 z 26.10.2012 r.

Laeken Declaration on the Future of the European Union, Bulletin of the European Union. Presidency Conclusions of the Laeken European Council (14 and 15 December 2001), Office for Official Publications of the European Communities, Luxembourg.

Traktat o Unii Europejskiej, Dz. Urz. UE C 326 z dnia 26 października 2012 r.

Rozporządzenie Parlamentu Europejskiego i Rady (UE) 2011/211 z dnia 16 lutego 2011 r. w sprawie inicjatywy obywatelskiej.

Rozporządzenie Parlamentu Europejskiego i Rady (UE) 2019/788 z dnia 17 kwietnia 2019 r. w sprawie europejskiej inicjatywy obywatelskiej.

\section{Streszczenie}

System polityczny Unii Europejskiej jest przykładem rządzenia odbywającego się w silnie zróżnicowanym środowisku kulturowym, społecznym i politycznym. Jego rozwój jest nieline- 
arny, a wyznaczenie jego granic okazuje się bardzo trudne lub wręcz niemożliwe. Traktat z Lizbony nie określił w sposób jednoznaczny dalszego kierunku rozwoju UE, a wręcz przyczynił się do pogłębienia złożoności systemowych. W sposób szczególny zjawisko to zarysowało się w obszarze rozwiązań instytucjonalnych, które kumulują wszelkie napięcia i kryzysy pojawiające się w procesie integracji. W wyjątkowy sposób do zwiększenia niespójności w systemie integracyjnym przyczyniła się komasacja zjawisk kryzysowych po 2009 roku. Jednocześnie obserwujemy specyficzne właściwości towarzyszące kształtowaniu się mechanizmów instytucjonalnych, które w odpowiedzi na powtarzające się trudności wykształciły zachowania elastyczne i odpornościowe. Efektem są przeobrażenia systemu instytucjonalnego, które kreują niejednorodne rozwiązania o tendencjach zarówno integrujących, jak i dezintegrujących system.

Słowa kluczowe: system polityczny UE, system instytucjonalny, złożoność procesu integracji europejskiej, demokracja, resilience, traktat z Lizbony

\section{Limits of the Development of the EU Political System after the Lisbon Treaty: the Question of the Complexity and Resilience of the European Institutional System}

\section{Summary}

The political system of the European Union is an example of governance realised in a highly diversified cultural, social and political environment. Its development is non-linear and determining its boundaries turns out to be very difficult or even impossible. The Treaty of Lisbon did not clearly define the further direction of the EU's development, and even contributed to the deepening of systemic complexities. This phenomenon is particularly visible in the area of institutional solutions that accumulate all tensions and crises that appear in the integration process. The amalgamation of crisis phenomena after 2009 contributed to an exceptional increase in inconsistencies in the integration system. At the same time, we observe specific properties accompanying the shaping of institutional mechanisms, which in response to repeated difficulties have developed flexible and resilient behaviors. The effect is transformations of the institutional system, which create heterogeneous solutions with both integrating and disintegrating tendencies.

Key words: Political system of the European Union, institutional system, complexity of the European integration process, democracy, resilience, Lisbon Treaty 
